\title{
Front Matter: Volume 7256
}

, "Front Matter: Volume 7256," Proc. SPIE 7256, Multimedia on Mobile Devices 2009, 725601 (6 February 2009); doi: 10.1117/12.824735

SPIE Event: IS\&T/SPIE Electronic Imaging, 2009, San Jose, California, United SPIE. States 


\title{
PROCEEDINGS \\ IS\&T/SPIE \\ Eleatronic \\ Imaging \\ Science and Technology
}

\section{Multimedia on \\ Mobile Devices 2009}

\author{
Reiner Creutzburg \\ David Akopian \\ Editors
}

19-20 January 2009

San Jose, California, United States

Sponsored and Published by

IS\&T-The Society for Imaging Science and Technology

SPIE 
The papers included in this volume were part of the technical conference cited on the cover and title page. Papers were selected and subject to review by the editors and conference program committee. Some conference presentations may not be available for publication. The papers published in these proceedings reflect the work and thoughts of the authors and are published herein as submitted. The publishers are not responsible for the validity of the information or for any outcomes resulting from reliance thereon.

Please use the following format to cite material from this book:

Author(s), "Title of Paper," in Multimedia on Mobile Devices 2009, edited by Reiner Creutzburg, David Akopian, Proceedings of SPIE-IS\&T Electronic Imaging, SPIE Vol. 7256, Article CID Number (2009).

ISSN 0277-786X

ISBN 9780819475060

Copublished by

SPIE

P.O. Box 10, Bellingham, Washington 98227-0010 USA

Telephone +1 3606763290 (Pacific Time) · Fax +1 3606471445

SPIE.org

and

IS\&T-The Society for Imaging Science and Technology

7003 Kilworth Lane, Springfield, Virginia, 22151 USA

Telephone +1 7036429090 (Eastern Time) · Fax +1 7036429094

imaging.org

Copyright (c) 2009, Society of Photo-Optical Instrumentation Engineers and The Society for Imaging Science and Technology.

Copying of material in this book for internal or personal use, or for the internal or personal use of specific clients, beyond the fair use provisions granted by the U.S. Copyright Law is authorized by the publishers subject to payment of copying fees. The Transactional Reporting Service base fee for this volume is $\$ 18.00$ per article (or portion thereof), which should be paid directly to the Copyright Clearance Center (CCC), 222 Rosewood Drive, Danvers, MA 01923. Payment may also be made electronically through CCC Online at copyright.com. Other copying for republication, resale, advertising or promotion, or any form of systematic or multiple reproduction of any material in this book is prohibited except with permission in writing from the publisher. The CCC fee code is 0277-786X/09/ $\$ 18.00$.

Printed in the United States of America.

Paper Numbering: Proceedings of SPIE follow an e-First publication model, with papers published first online and then in print and on CD-ROM. Papers are published as they are submitted and meet publication criteria. A unique, consistent, permanent citation identifier (CID) number is assigned to each article at the time of the first publication. Utilization of CIDs allows articles to be fully citable as soon they are published online, and connects the same identifier to all online, print, and electronic versions of the publication. SPIE uses a six-digit CID article numbering system in which:

- The first four digits correspond to the SPIE volume number.

- The last two digits indicate publication order within the volume using a Base 36 numbering system employing both numerals and letters. These two-number sets start with 00, 01, 02, 03, 04, 05 , 06, 07, 08, 09, OA, OB ... 0Z, followed by 10-1Z, 20-2Z, etc.

The CID number appears on each page of the manuscript. The complete citation is used on the first page, and an abbreviated version on subsequent pages. Numbers in the index correspond to the last two digits of the six-digit CID number. 


\section{Contents}

vii Conference Committee

\section{SESSION 1 SECURITY AND SERVICES FOR MOBILE DEVICES}

725602 A secure wireless mobile-to-server link (Invited Paper) [7256-01]

A. Kumar, D. Akopian, S. Agaian, The Univ. of Texas at San Antonio (United States);

R. Creutzburg, Fachhochschule Brandenburg (Germany)

725603 Image encryption based on edge information [7256-02]

Y. Zhou, K. Panetta, Tufts Univ. (United States); S. Agaian, The Univ. of Texas at San Antonio (United States)

\section{SESSION 2 MOBILE MEDIA CODING AND PROCESSING}

725605 On-demand learning system using 4K video source [7256-04]

A. Yutani, Y. Manabe, H. Sunahara, K. Chihara, Nara Institute of Science and Technology (Japan)

725606 Adaptive timeline aware client controlled HTTP streaming [7256-05]

S. Deshpande, Sharp Labs. of America (United States)

725607 Progressive raster imagery beyond a means to overcome limited bandwidth [7256-06]

R. Rosenbaum, H. Schumann, Univ. of Rostock (Germany)

725608 H.264/AVC intra-only coding (iAVC) techniques for video over wireless networks [7256-07] M. Yang, M. Trifas, Jacksonville State Univ. (United States); G. Xiong, Huanyu Autolighting Co., Ltd. (China); J. Rogers, Jacksonville State Univ. (United States)

725609 New side information-generation method based on multiple reference frames for distributed video coding [7256-08]

R. K. Liu, Z. Yue, W. Hu, Beijing Univ. (China)

\section{SESSION $3 \quad$ LARGE MEDIA PROCESSING}

7256 OA Resource-saving image browsing based on JPEG2000, blurring, and progression [7256-09] R. Rosenbaum, H. Schumann, Univ. of Rostock (Germany)

7256 OC Adaptation of web pages and images for mobile applications [7256-11] S. Kopf, B. Guthier, H. Lemelson, W. Effelsberg, Univ. of Mannheim (Germany)

7256 OD Graphics hardware accelerated panorama builder for mobile phones [7256-12] M. Bordallo López, J. Hannuksela, O. Silvén, Univ. of Oulu (Finland); M. Vehviläinen, Nokia Research Ctr. (Finland) 
7256 OE An affordable wearable video system for emergency response training (Invited Paper) [7256-13]

D. King-Smith, A. Mikkilineni, D. Ebert, T. Collins, E. J. Delp, Purdue Univ. (United States)

7256 OF Development of mobile preventive notification system (PreNotiS) [7256-14]

A. Kumar, D. Akopian, P. Chen, The Univ. of Texas at San Antonio (United States)

7256 OG An assisted GPS support for GPS simulators for embedded mobile positioning [7256-15] P. Kashyap, The Univ. of Texas at San Antonio (United States); A. Samant, National Instruments (India); P. K. Sagiraju, D. Akopian, The Univ. of Texas at San Antonio (United States)

$7256 \mathrm{OH} \quad$ Contextual interaction for geospatial visual analytics on mobile devices [7256-16] A. Pattath, D. S. Ebert, Purdue Univ. (United States); W. Pike, R. A. May, Pacific Northwest National Lab. (United States)

\section{SESSION $5 \quad$ 3D VIDEO DELIVERY FOR MOBILE DEVICES}

7256 OJ Mobile 3D television: development of core technological elements and user-centered evaluation methods toward an optimized system (Invited Paper) [7256-18]

A. Gotchev, Tampere Univ. of Technology (Finland); A. Smolic, Fraunhofer HHI (Germany); S. Jumisko-Pyykkö, Tampere Univ. of Technology (Finland); D. Strohmeier, Ilmenau Univ. of Technology (Germany); G. Bozdagi Akar, Middle East Technical Univ. (Turkey); P. Merkle, Fraunhofer HHI (Germany); N. Daskalov, Multi-Media Solutions, Ltd. (Bulgaria)

7256 OK Verification of 3D mobile broadcasting service based on depth-image based rendering technique in terrestrial-DMB [7256-19] G. Lee, H. Lee, K. Yun, B. Lee, N. Hur, J. W. Kim, Electronics and Telecommunications Research Institute (Korea, Republic of); K. Jung, Y. K. Park, J. K. Kim, Sungkyunkwan Univ. (Korea, Republic of)

7256 OL Use scenarios: mobile 3D television and video [7256-20] D. Strohmeier, IImenau Univ. of Technology (Germany); M. Weitzel, S. Jumisko-Pyykkö, Tampere Univ. of Technology (Finland)

7256 OM Imaging and display systems for 3D mobile phone application [7256-21] M.-C. Park, Korea Institute of Science and Technology (Korea, Republic of); J.-Y. Son, Daegu Univ. (Korea, Republic of)

7256 ON Efficient stereoscopic contents file format on the basis of ISO base media file format [7256-22]

K. Kim, J. Lee, D. Y. Suh, G. H. Park, Kyunghee Univ. (Korea, Republic of) 
7256 OP Perceptual quality measurement for scalable video at low spatial resolution in mobile environments [7256-24]

H. Sohn, H. Yoo, C. S. Kim, W. De Neve, Y. M. Ro, Information and Communications Univ. (Korea, Republic of)

7256 OQ A location-based notification- and visualization-system indicating social activities [7256-25] S. David, S. Edlich, TFH Berlin (Germany)

7256 OR An Android based location service using GSMCellID and GPS to obtain a graphical guide to the nearest cash machine [7256-26]

J. Jacobsen, S. Edlich, TFH Berlin (Germany)

Author Index 
Downloaded From: https://www.spiedigitallibrary.org/conference-proceedings-of-spie on 26 Apr 2023

Terms of Use: https://www.spiedigitallibrary.org/terms-of-use 


\title{
Conference Committee
}

\author{
Symposium Chairs
}

Nitin Sampat, Rochester Institute of Technology (United States)

Jan P. Allebach, Purdue University (United States)

Conference Chairs

Reiner Creutzburg, Fachhochschule Brandenburg (Germany)

David Akopian, The University of Texas at San Antonio (United States)

Program Committee

Sos S. Agaian, The University of Texas at San Antonio (United States)

Alan Chalmers, University of Bristol (United Kingdom)

Linda Breitlauch, Mediadesign Hochschule Düsseldorf (Germany)

Jianfei Cai, Nanyang Technological University (Singapore)

Surendar Chandra, University of Notre Dame (United States)

Chang Wen Chen, Florida Institute of Technology (United States)

Kenneth J. Crisler, Motorola, Inc. (United States)

David Scott Doermann, University of Maryland, College Park

(United States)

Uwe Dummann, Siemens AG (Germany)

Elizabeth Dykstra-Erickson, Kinoma, Inc. (United States)

Stefan Edlich, Technische Fachhochschule Berlin (Germany)

Lajos Hanzo, University of Southampton (United Kingdom)

Zhihai He, University of Missouri, Columbia (United States)

Hendrik O. Knoche, University College London (United Kingdom)

Xin Li, West Virginia University (United States)

Manzur M. Murshed, Monash University (United States)

Sethuraman Panchanathan, Arizona State University (United States)

Kari A. Pulli, Nokia Research Ctr. Palo Alto (United States)

Matthias Rauterberg, Technische Universiteit Eindhoven (Netherlands)

Phillip A. Regalia, Institut National des Télécommunications (France)

Thomas Schwotzer, Fachhochschule Brandenburg (Germany)

Olli J. Silvén, University of Oulu (Finland)

Jarmo H. Takala, Tampere University of Technology (Finland)

Kaisa Anneli Väänänen-Vainio-Mattila, Tampere University of

Technology (Finland)

Haitao Zheng, University of California, Santa Barbara (United States) 


\section{Session Chairs}

1 Security and Services for Mobile Devices

Sos S. Agaian, The University of Texas at San Antonio (United States)

David Akopian, The University of Texas at San Antonio (United States)

2 Mobile Media Coding and Processing

Reiner Creutzburg, Fachhochschule Brandenburg (Germany)

3 Large Media Processing

Olli J. Silvén, University of Oulu (Finland)

Reiner Creutzburg, Fachhochschule Brandenburg (Germany)

4 Safety and Location

David Akopian, The University of Texas at San Antonio (United States)

Helmar Burkhart, University of Basel (Switzerland)

5 3D Video Delivery for Mobile Devices

Namho Hur, Electronics and Telecommunications Research Institute (Korea, Republic of)

Atanas P. Gotchev, Tampere University of Technology (Finland) 